\title{
What is gender-responsive legislation? Using international law to establish benchmarks for labour, reproductive health and tax laws that work for women
}

\author{
Dr Ramona Vijeyarasa, Faculty of Law, UTS
}

This is a pre-publication version which appears in (2021)

Griffith Law Review 29 (3), pp. 334-350

The definitive version is available at https://doi-

org.ezproxy.library.sydney.edu.au/10.1080/10383441.2020.1853900

\begin{abstract}
For decades, the world has seen legal, policy and practical interventions to advance women's rights. Yet there is no country in the world where women and men are equal. In pursuit of such equality, this article promotes the relatively obvious and simple strategy of embedding international women's rights norms into domestic legislation. While acknowledging the limitations of the binary approach to the rights of men and women as reinforced by the CEDAW Convention, the article draws from international law to offer standards for domestic legislation in three areas: reproductive health, labour law and taxation. Across those areas, concrete templates for gender-responsive legislation are provided, as well as examples of what constitutes neutral, blind and regressive provisions. While acknowledging the limits of the law in disrupting the political and economic structures of society, this article offers a framework that can enable legislators and legal systems to utilise international law to deliver domestic laws that work for women.
\end{abstract}

\section{Introduction}

There is no country in the world where women and men are equal. ${ }^{1}$ Despite an enormous global investment in advancing gender equality and women's rights around the globe, women continue to experience persistent discrimination and inequality by virtue of being women, even years after Ann Tickner first stated this sadly obvious but true point. ${ }^{2}$ However, there have been extensive multi-pronged strategies to address gendered differences in women's well-being, access and status. This includes interventions from the grassroots through to temporary special measures such as quotas and global policy-oriented initiatives with gender equality targets in

\footnotetext{
${ }^{1}$ World Economic Forum, 'The Global Gender Gap Report 2020,' http://www3.weforum.org/docs/WEF_GGGR_2020.pdf, 2020.

${ }^{2}$ Tickner (2004), pp 6.
} 
the Sustainable Development Goals. All have been the subject of both praise,$^{3}$ and more often, extensive debate and critique. ${ }^{4}$

Yet, only recently has there been a determined push to explore a relatively obvious and simple strategy, embedding international women's rights norms into domestic legislation. Indeed, the failure of many constitutional and legal systems to integrate women's human rights fully into domestic law was the impetus for the United Nations Human Rights Council to establish a working group on discrimination against women and girls. ${ }^{5}$ In May 2019, the utility of the law as a strategy to advance women's rights was politically endorsed at the G7 summit which declared inclusive laws as 'one of the key enablers for equality between women and men'. ${ }^{6}$ This followed a 2019 World Bank report which identified legislative barriers as the biggest obstacle, on a global scale, to women's empowerment in world economies. ${ }^{7}$ The challenge now lies in the academic space to provide a sound and practical understanding of what gender-responsive legislation means in theory and looks like in practice.

The first obstacle to deliver gender equality through the law is the wider issue of the gendered nature of the law itself. Legal systems are neither blind to sex (as they so often claim to be) nor objective. As Charlesworth, Chinkin and Smart have powerfully argued about international law generally, ${ }^{8}$ the international human rights mechanisms ${ }^{9}$ and domestic legal systems, ${ }^{10}$ the law at best excludes women's perspectives or at worst, sustains women's oppression. When women are subjects of the law, they are frequently conceptualised as primarily the victims of violations of bodily integrity. What results is an inadequate understanding of the full scope of violations suffered by women. ${ }^{11}$ Gender is frequently considered relevant to a particular sub-set of concerns - gender-based violence, reproductive health and the family - while gender is often not considered relevant when it comes to issues

\footnotetext{
${ }^{3}$ Otto (2019), afterword.

${ }^{4}$ Vijeyarasa (2010), pp 93, True (2003) pp 368, Esquivel and Sweetman (2016) 24(1) pp 1.

${ }^{5}$ Office of the High Commissioner for Human Rights, 'Working Group on Discrimination against Women and

Girls,' https://www.ohchr.org/en/issues/women/wgwomen/pages/wgwomenindex.aspx, 2019.

${ }^{6}$ Group of 7, 'Declaration on Gender Equality,' https://www.egalite-femmes-hommes.gouv.fr/wpcontent/uploads/2019/05/G7-Gender-Equality-Declaration.pdf.

${ }^{7}$ World Bank, 'Women, Business and the Law 2019: A Decade of Reform' https://openknowledge. worldbank.org/bitstream/handle/10986/31327/WBL2019.pdf? sequence=4\&isAllowed=y 2019.

${ }^{8}$ Charlesworth and Chinkin (2000).

${ }^{9}$ Charlesworth (2018), pp 103.

10 Smart (1989).

${ }^{11}$ Vijeyarasa (2013), pp 368 and Otto (2019), pp 533.
} 
such as bankruptcy, trade or financial regulation. ${ }^{12}$ In Australia, while we have made 'heartening' progress in acknowledging the need for a gender perspective in taxation and fiscal policy, ${ }^{13}$ gaps remain.

The law is, therefore, a problem but can also be the solution. We must acknowledge the extent to which the law can and does play a role in shifting social norms for the better, a role exercised by both domestic and international law. Compulsory education helped shift social views about the need to send both boys and girls to school. ${ }^{14}$ International law played a direct role in the prohibition of polygamy ${ }^{15}$ while simultaneously shifting social attitudes against the practice. In recent times, laws on same-sex marriage demonstrate the power of the law to promote social and cultural equality for same-sex couples. ${ }^{16}$

The law must therefore play its role in correcting the inequality suffered by women. This notion of the law's correctional role encompasses the idea of gender-responsive legislation. ${ }^{17}$ Gender-responsive legislation entails laws that are more responsive to explicit and implicit gender issues. Such legislation facilitates accountability, in legislative and policy implementation, to the specific needs of different sexes and to different gendered perspectives on pivotal social, economic and political issues. ${ }^{18}$

This article will provide the templates for gender-responsive legislation in several areas of law by drawing from international hard and soft law and the standards offered by such international legal instruments that can enable domestication of human rights norms. The end goal is domestic legislation that works more effectively to advance women's rights. International law in some ways is the ideal benchmark for this end goal. Global standards cut across the complex dynamics that exist in different jurisdictions - institutional, cultural and otherwise - and provide a fair comparison to assess progress.

This analysis is part of a broader project - the design and implementation of the Gender Legislative Index (GLI) - that aims to enable legislators and the legal system to deliver laws that work for women. This article contributes by defining gender-responsive legislation and

\footnotetext{
12 Warren (2002).

${ }^{13}$ Stewart (2017), pp. 3.

${ }^{14}$ Vijeyarasa (2019), pp 275.

${ }^{15}$ Committee on the Elimination of Discrimination against Women (1990) General Recommendation 21: Equality in Marriage and Family Relations, U.N. Doc. A/45/38.

${ }^{16}$ Hull (2003), pp 629.

17 Vijeyarasa (2019).

18 Vijeyarasa (2019).
} 
setting out concrete examples of laws that achieve this and laws that fail to do so. The primary goal is to ensure that laws that are good for women get on the books in the first place. While the law can only go so far in disrupting the political and economic structures of society, even the law's harshest critiques acknowledge the importance of enacting good laws and reforming poor ones i.e. getting the law right is the first step in a long-term path towards social change. ${ }^{19}$ In fact for countries that rank high on the rule of law index, ${ }^{20}$ gender-responsive laws on paper are a realistic and feasible strategy in which to invest to advance gender equality and correct discrimination.

For this purpose, I have chosen three areas of law to offer concrete examples of genderresponsive, gender-neutral, gender-blind and gender-regressive legislation. First, reproductive health is an area of law often considered core to women's human rights. It reflects an important, but at times excessive, ${ }^{21}$ focus on women's bodies as the site of concern. Second, legislation to regulate workplace practices is often male centric, reinforcing norms that are blind to women experiences of the law. ${ }^{22}$ Nonetheless, important advances have been made in recent years regarding how women and their rights are specifically affected in workplaces. Finally, taxation is an area rarely considered from a gender perspective. ${ }^{23}$ As such, it has been included to counter the tendency to examine gender in only a very narrow subset of areas and to bring visibility to importance of gender in this area of law.

Before continuing, it is important to make a note on the use of the terms 'gender' and 'women' in this article. This article is focused on women's rights quite deliberately. It draws on the standards established in international women's rights law, primarily the Convention on the Elimination of All Forms of Discrimination against Women (CEDAW) ${ }^{24}$ and it seeks to promote legislation that can move society towards a situation of greater equality between men and women. It is not intended to exclude - for example, non-cisgender women - or to assimilate - for instance, by placing all women into a monolithic category and failing to acknowledge difference. To the contrary, the category of 'women' is intended to be political and not

\footnotetext{
${ }^{19}$ Crenshaw (1988), pp 1331.

${ }^{20}$ World Justice Project, 'Rule of Law Index 2020'

$<$ https://worldjusticeproject.org/sites/default/files/documents/WJP-ROLI-2020-Online_0.pdf>, 2020.

${ }^{21}$ Kapur (2013), pp 14.

22 Chapman (2018).

${ }^{23}$ Carpraro (2017), pp 491.

${ }^{24}$ CEWDAW: Convention on the Elimination of All Forms of Discrimination against Women 1979, Adopted 18 December 1979, GA Res 34/180, entry into force 3 September 1981. OR Convention on the Elimination of All Forms of Discrimination against Women 1979 opened for signature Mar 1 1980, entered into force Sept. 31981.
} 
essentialist. ${ }^{25}$ It is justified by asking the question, who is left out of current legal frameworks and structures. ${ }^{26}$

Unfortunately, the international human rights system has been slow to progress and address the significant limitations of the male/female binary. In turn, this binary lens informs other interventions by international human rights actors: where sexual violence is framed within a male perpetrator/female victim framework, interventions are defined in a way that can and do ignore violence outside of this heteronormative framework. ${ }^{27}$ Other scholars have identified the gender essentialism that results from international law's attempts to create a universal set of rules that are then applied across communities. There are obvious, but often ignored limitations, for example, in attempting to apply the same set of standards to both conflict and post-conflict settings. ${ }^{28}$ The very design of the international human rights system is such that it is entrenched in this universalising approach, that creates a whole host of problematic binaries, not just male/female, or heteronormative and 'non-normative'. Dianne Otto, in calling out the desperate need to reframe international law, has been quick to remind us that challenging heteronormativity should be a collective struggle; new frameworks that both feminist and queer scholarship offers can build greater solidarity, promote redistributive values, challenge inequalities, advance peace and ensure environmental sustainability. ${ }^{29}$

In this article, I do not wish to ignore the problematics behind a binary approach but rather to use international law which provides a common benchmark against which all countries can strive. This article seeks to work with the standards that we have and to improve the approach taken within that framework. While I would like to see the framework itself enriched to respond to these criticisms as best possible, this is beyond the scope of this project. Therefore, taking the existing parameters offered by CEDAW, albeit at times limited, allows us to move forward towards greater accountability, even if it does require accepting some of the limitations behind CEDAW's often binary and too frequently heteronormative approaches.

\section{Key concepts: From gender-regressive to gender-responsive laws that work for women} A scale from regressive to responsive

\footnotetext{
${ }^{25}$ Ramji-Nogales (2019), pp 242.

${ }^{26}$ Ramji-Nogales (2019), pp 242.

${ }^{27}$ Paige (2017), pp 92.

${ }^{28}$ Heathcote (2012), pp 85.

${ }^{29}$ Otto (2017), pp 2.
} 
This article is premised on the responsibility of states to set up an enabling environment that facilitates the enactment of gender-responsive laws. The call for legislation that somehow acknowledges and responds to the ways in which women are specifically affected by the law is not new. In fact, it has been pursued by domestic and international feminist legal scholars for decades, albeit using different terminology. Historical studies of 'laws for women' have been undertaken at length, often examining the laws affecting women workers, particularly in relation to equal pay for equal work. ${ }^{30}$

More recently, the language has shifted to 'disruption' of norms and practices. There has been a call, for instance, for an overhaul to approaches in health systems, where there is a distinct inequality in the experiences of male and female healthcare workers and where women as patients face gender-specific barriers in their access to health care. ${ }^{31}$ The ways in which gender equality has been understood and pursued through the realm of public law has also been analysed, from gendered inequalities reinforced in nationality laws through to how gender is addressed in new constitutions in post-conflict contexts. ${ }^{32}$ Legislation cannot be viewed in isolation from the lawmakers themselves. The steps to create gender-sensitive parliaments that may enhance the possibility of enacting gender-responsive legislation are multi-pronged and complex. These have also been interrogated. ${ }^{33}$

Despite all of these endeavours, there has still been a mixed level of success in defining what such gender-responsive, or 'gender-sensitive' legislation ${ }^{34}$ actually looks like. This is despite the political will expressed in support of such an approach. ${ }^{35}$ With this background in mind, this section seeks to define for readers what that scale from gender-regressive to genderresponsive actually looks like.

\section{Gender-regressive}

Gender-regressive legislation sits in direct opposition to global standards on women's rights. Contrary to evidenced-based needs and interests of women and girls, such legislation overtly

\footnotetext{
${ }^{30}$ Woloch (2015), pp 1 and Mccammon (1995).

31 Hay et al (2019), pp 2535.

32 Rubenstein and Young (2016).

${ }^{33}$ Wangnerud (2015) and Cope (1997).

${ }^{34}$ European Institute for Gender Equality, 'Area 4: The Parliament Produces Gender-Sensitive Legislation', https:/eige.europa.eu/gender-mainstreaming/toolkits/gender-sensitive-parliaments/examples-gender-sensitivepractices-parliaments/area-4-parliament-produces-gender-sensitive-legislation, 2020.

${ }^{35}$ Group of 7, 'Making Gender Equality a Global Cause,' https://www.elysee.fr/admin/upload/default/0001/05/2d0396362dbe1fb85faccb8e1f5dbefce5a0b09e.pdf.
} 
opposes a gendered response. Not only are gendered considerations ignored, but the legislation explicitly or implicitly places women in a less developed state in terms of their social, economic and political status and overall well-being. The criminalisation of abortion in several countries across the world serves as an example of gender-regressive laws. ${ }^{36}$ Countries that not only deny women access to safe and legal abortion services but in fact criminalise women and their providers demonstrate a complete disregard for women's rights.

\section{Gender-blind}

Gender-blind legislation shows a lack of awareness of men's and women's specific and different needs and interests altogether. Overt gender issues and considerations have been clearly ignored. When regulating urban planning, a gender blind law may attempt to make low-cost public transport available for all, but would fail to consider women's specific needs such as reflected in a spate of global studies on women's experiences of unsafe cities. ${ }^{37}$ This would include a failure to guarantee access to transport at hours relevant for women informal workers or those doing shift work; not ensuring adequate street lighting at night near bus terminals and other transport hubs; or a failure to criminalise sexual harassment in public spaces.

\section{Gender-neutral}

Gender-neutral legislation makes no effort and in fact might deliberately avoid making distinctions on the basis of gender or sex. There may be instances where a gender perspective may not be considered necessary. For example, a law may merely extend the operation of a previous law and a gendered perspective may simply not be applicable. A law that changes the name of a public high school from "Agricultural High School" to a "Vocational High School" may also be inconsequential from a gender perspective.

However, gender-neutrality may easily slip - particularly when it comes to enforcement - into a "gender-blind" response to an issue, particularly where gender ought to have been considered. In the area of financial services regulation, a law that guarantees women access to a bank loan without needing the signature of a male counter-part would often be considered gender-neutral for guaranteeing neutral treatment of male and female applicants, countering

\footnotetext{
${ }^{36}$ Zampas and Gher (2008), pp 249.

${ }^{37}$ ActionAid, 'Safe Cities for Women,' http://www.actionaid.org/safecitiesforwomen, 2016 and UN Women, 'Safe Cities and Safe Public Spaces: Global Results Report,' http://www.unwomen.org/en/digitallibrary/publications/2017/10/safe-cities-and-safe-public-spaces-global-results-report, 2017.
} 
past practices that tended to require a male relative's signature for female applicants. ${ }^{38}$ However, the GLI would not classify such a law as "neutral" as a gender-perspective is indeed required.

Instead, the law may be classified as gender-blind, or even gender-regressive in its effect, if enacted in the context of legal systems where inheritance rights discriminate against women, making it even less likely for women to own collateral in their own name. A genderresponsive law in this context would facilitate women's easier access to credit despite not having property or collateral in their name, with particular acknowledgement of marginalised or excluded groups of women.

It is important, too, to recognise that a seemingly gender-neutral law could in fact be gender-blind. For example, the decision to rename a street, district, province, hospital or school may seemingly not require a gender perspective. However, if ten main streets in a town were renamed to reflect male national heroes, without a single female national hero being included, such a law would quickly slip into the category of gender-blind.

\section{Gender-responsive}

Gender-responsive legislation makes legislative systems more responsive to explicit and implicit gender issues. It facilitates accountability - in legislative and policy implementation to the specific needs of different sexes and to different gendered perspectives on pivotal social, economic and political issues. A regulation that simplifies banking practices to reach more women, including for instance, reducing the minimum deposit and other requirements for opening up a bank account for female applicants, would be gender-responsive. ${ }^{39}$ In some contexts, this type of legislation would be classified as positive discrimination. In the area of health, a law that guarantees all women, both married and unmarried, adolescents as well as adult women, access to age-appropriate, scientifically evidence-based comprehensive family planning services and information would be gender-responsive.

These definitions have been provided as background contexts. With these terms in mind, in the following section, I specifically turn to international law to offer concrete benchmarks for achieving gender-responsive laws and shifting away from regressive ones.

\footnotetext{
${ }^{38}$ Buttner (1993), pp 59.

${ }^{39}$ Beijing Declaration and Platform of Action (1995), adopted at the Fourth World Conference on Women 1995 (UN Doc. A/CONF. 177/20 1995 and A/CONF. 177/20/Add. 1 (1995) 63(c)), endorsed by GA Resolution 50/203, 22 December 1995.
} 


\section{Using international law to go from theory to practice: Gender-responsive laws in the areas of reproductive health, labour and taxation}

International law offers a solid basis for the identification of global benchmarks. By using the standards of international women's rights law and specifically, CEDAW as the basis upon which to determine what constitute 'good laws for women', this analysis draws upon agreed principles that apply across jurisdictions and cultural boundaries and with which States themselves have agreed to comply. ${ }^{40}$ Importantly, CEDAW, the only international human rights treaty exclusively focused on discrimination between men and women, has achieved almost universal ratification.

Drawing from global benchmarks, this section offers concrete standards for genderresponsive legislation. In order to do this, however, it is important to set out the expected scope of gender-responsive issues to be address in law, regardless of the area of law. In order to establish these categories, I have analysed CEDAW's 37 General Recommendations, issued from 1986 to 2018. They have been coded, that is, broken down and grouped into categories' To undertake this analysis, the approach of grounded theory was applied. In short, grounded theory is the discovery of a theory from data. ${ }^{41}$ By observing data, grounded theory allows for the identification of relationships between different categories, from which a theory can emerge. ${ }^{42}$ While NVivo Software was used to assist the process, the method went beyond merely attaching labels to particular recommendations, concepts and categories and instead to a more reflective approach. My goal was to concretely extract recommendations or criteria as set out by the CEDAW Committee - for policy and legal reform.

Only "recommendations" i.e. directions from the CEDAW Committee to States or other UN entities, have been coded. Contextual information such as observations (e.g. "Having observed" or "Considering" or "Recalling") have not been coded. All contextual information was removed to ensure only direct recommendations were coded. This approach was adopted to create criteria for law and policy reform based only on what the Committee was concretely advising States to do in that particular recommendation i.e. how its legislative and policy response should be prioritised when it comes to women's rights, and not its reference to contextual shortcomings and issues, past recommendations, or recommendations made by other UN entities.

\footnotetext{
40 Vijeyarasa (2021).

${ }^{41}$ Glaser and Strauss (1968).

${ }^{42}$ Urquhart (2013), pp 8.
} 
In the early years (1986 to 1989), many recommendations were brief (less than $1 / 2$ page). By General Recommendation No. 31 in 2014, the Committee distinguished its contextual analysis from recommendations by making the text of all direct recommendations bold, which both facilitated my method but also highlighted the appropriateness of this approach. At this stage, recommendations spanned over more than twenty pages.

This process resulted in a set of criteria that focused on all of the recommendations directed by the CEDAW Committee at States Parties for legal and policy reform i.e. actions to be taken as listed in Table 1:

Table 1: Key asks of the CEDAW Committee to States Parties: Findings from an analysis of 37 General Recommendations from 1986 to 2018

1. Does the law guarantee access to non-discriminatory and accessible, affordable, acceptable services?

2. Does the law guarantee access to information and education or require the provision of information and education on the issue?

3. Does the law guarantee non-coerced and informed decision-making and where relevant, protect women's confidentiality?

4. Does the law promote equal relations between men and women?

5. Does the law protect women from situations of vulnerability linked to their gender?

6. Does the law guarantee accessible and effective remedies (i.e. access to justice)?

7. Does the law promote the comprehensive monitoring of the situation of women? This includes promoting gender-disaggregated data collection on the nature of the problem

In the following sub-sections, I set out concrete examples of potential inclusions in the law, in relation to the above seven criteria and per one of the three areas, derived from international law. To the greatest extent possible, these benchmarks strictly adhere to the language that appears in the global commitments (primarily international human rights treaties or ILO Conventions), neither reducing them nor expanding them. In instances where no binding international law could be identified, this article offers benchmarks from regional agreements that are relevant to that area of law. 
Only select examples of benchmarks are provided in this article. ${ }^{43}$ The purpose of providing these examples is not to be exhaustive but rather to offer standards across all seven categories to demonstrate the viability of this approach. The ability to identify benchmarks, across the seven categories listed in Table 1, and across three relatively divergent areas of law - reproductive health, labour law and taxation - demonstrates that it is indeed feasible for legislators to pursue gender-responsive outcomes in their tabling of laws.

\section{Sexual and Reproductive Rights and Health}

Women's sexual and reproductive health and rights, which has long been acknowledged as a fundamental women's rights issue, has been the pursuit of women's rights advocates for decades. ${ }^{44}$ Reproductive rights rest on the recognition of all couples and individuals to decide freely and responsibly the number, spacing and timing of their children (if they indeed decided to have any), and the means to do so, and the right to attain the highest standard of sexual and reproductive health. It also includes the right to make decisions concerning reproduction free of discrimination, coercion and violence. ${ }^{45}$ The CEDAW Committee has also discussed women's reproductive rights extensively in its own jurisprudence. ${ }^{46}$

Within the regulatory area of reproductive health, a gender-responsive law, that meets the requirement to guarantee women access to non-discriminatory and accessible, affordable, acceptable services (Criteria 1) would guarantee access to all reproductive-related health services including family planning, antenatal, maternity, post-natal services and safe legal abortion which is free and accessible for all women. ${ }^{47} \mathrm{~A}$ law that has a user-pay system, applied in the same manner to all users, might be seemingly neutral. However, such a law would fail to acknowledge the financial barriers particular groups of women may face - including those that do not have control over the family income, women single-heads of households and lowincome women or women living in poverty. This would fail to meet CEDAW's recommendation that the law provides free services where necessary. ${ }^{48}$

\footnotetext{
${ }^{43}$ For a more comprehensive set of benchmarks, visit the Gender Legislative Index at www.genderlawindex.org.

${ }^{44}$ Cook, Dickens and Bliss (1999), pp 579 and Cook (1991), pp 645.

${ }^{45}$ Beijing Declaration and Platform of Action, Adopted at the Fourth World Conference on Women, paragraph 223.

${ }^{46}$ Alyne da Silva Pimentel v Brazil [2011] UN Committee on the Elimination of Discrimination against Women Communication No. 17/2008 and L C v Peru [2011] UN Committee on the Elimination of Discrimination against Women Communication No. 22/2009

${ }^{47}$ Committee on the Elimination of Discrimination against Women (1990) General Recommendation 24: Article 12 of the Convention, Women and Health, U.N. Doc. A/54/38

${ }^{48}$ Convention on the Elimination of All Forms of Discrimination against Women, Article 12(2).
} 
When it comes to guaranteeing non-coerced and informed decision-making for women (Criteria 3), a gender-responsive law would guarantee couples and individuals the right to choose the number, spacing and timing of the birth of their children. ${ }^{49}$ A gender-responsive approach requires that the delivery of health care services is in conformity with women's fully informed consent and in a way that respects a woman's dignity, guarantees her confidentiality and is sensitive to her needs and perspectives. ${ }^{50}$ A law that fails to provide a supportive environment for women to breastfeed ${ }^{51}$ and ensure women's access to appropriate services in connection with adequate nutrition during pregnancy and lactation ${ }^{52}$ could prove blind to women's needs. A gender-regressive law would permit harmful, medically unnecessary or coercive medical interventions, as well as inappropriate medication and over-medication of women contrary to global commitments. ${ }^{53}$

The decriminalisation of access to abortion across multiple Australian jurisdictions is a shift towards gender-regressive legislation, reflecting a fundamental move away from the common approach of criminalising access to abortion with exemptions - commonly based on the nature of the conception (rape or incest), the condition of the pregnancy (dependent on the life and health of the mother) or state of the foetus (foetal anomaly) ${ }^{54}$ Even within this health law framework, however, particular provisions - related to counselling or gestational limits for instance - can advance or undermine women's autonomy. Such laws may reflect a genderregressive or gender-responsive approach, within a gender-responsive law.

\section{Labour}

The need to adopt a gender perspective when drafting laws to address workplaces has been a practice for several decades. Issues such as equal pay for equal work have long been recognised as core labour-rights principles. ${ }^{55}$ In more recent times, global standards have also evolved in relation to sexual harassment at work, particularly reaching a peak in 2019 with the ILO Convention on the Elimination of Violence and Harassment in the World of Work. ${ }^{56}$

\footnotetext{
${ }^{49}$ Programme of Action of the United Nations International Conference on Population and Development 1994 (UN Doc. A/CONF. 171/13) paragraph 7.14(a).

${ }^{50}$ Committee on the Elimination of Discrimination against Women (1990) General Recommendation 24: Article 12 of the Convention, Women and Health, U.N. Doc. A/54/38.

${ }^{51}$ International Code of Marketing of Breast-Milk Substitutes 1981, Article 6.

${ }^{52}$ Convention on the Elimination of All Forms of Discrimination against Women, Article 12(2).

${ }^{53}$ Beijing Declaration and Platform of Action, Adopted at the Fourth World Conference on Women, paragraph 106(h).

${ }^{54}$ Flowers (2020) and Millbank (2021).

${ }^{55}$ ILO Convention on Discrimination (Employment and Occupation) 1958.

${ }^{56}$ ILO Convention on the Elimination of Violence and Harassment in the World of Work 2019.
} 
A gender-responsive law that meets the requirement to promote equality between men and women (Criteria 4) would guarantee men and women the same employment opportunities, including the same employment opportunities and conditions, the application of the same selection criteria ${ }^{57}$ and the right to free choice of profession and employment, promotion, job security, vocational training and retraining. ${ }^{58} \mathrm{~A}$ gender-responsive law would also guarantee women equal remuneration, including benefits and equal treatment in respect of equal work and equal treatment in respect to the evaluation of the quality of the work. ${ }^{59}$

A law that facilitates trade union representation may be seemingly neutral. However, a law that fails to promote the election of women trade union officials and ensures that trade union officials elected to represent women are given job protection and physical security in connection with the discharge of their functions ${ }^{60}$ would be gender-blind. Rather, the law should specifically recognise unionisation and collective bargaining as a right and an important mechanism for eliminating wage inequality for women and to improve working conditions. ${ }^{61}$ A law that actual denies women-only unions could move into the realm of regressive, if it leaves groups of at-risk or vulnerable women unrepresented.

When it comes to protecting women from specific situations of vulnerability linked to their gender (Criteria 5), a gender-responsive law would prohibit violence and harassment against women, including physical, sexual, psychological and economic violence and harassment in the world of work. ${ }^{62}$ Such a law could be gender-regressive, however, if it explicitly excluded from these protections domestic and migrant workers and those at risk of forced and exploitative labour. ${ }^{63} \mathrm{~A}$ gender-responsive law would also prohibit direct and indirect gender discrimination in the labour market, including on the grounds of marriage, maternity/family status, pregnancy, paid maternity leave. ${ }^{64}$ This right to equality and non-

\footnotetext{
${ }^{57}$ Convention on the Elimination of All Forms of Discrimination against Women, Article 11(1)(b).

58 Convention on the Elimination of All Forms of Discrimination against Women, Article 11(1)(c).

59 Convention on the Elimination of All Forms of Discrimination against Women, Article 11(1)(d)) and ILO Equal Remuneration Convention (No. 100) 1951, Article 2(1).

${ }^{60}$ Beijing Declaration and Platform of Action, Adopted at the Fourth World Conference on Women, paragraph178(i).

${ }^{61}$ Beijing Declaration and Platform of Action, Adopted at the Fourth World Conference on Women, paragraph 178(h).

62 Beijing Declaration and Platform of Action, Adopted at the Fourth World Conference on Women, paragraph 180(c) and Committee on the Elimination of Discrimination against Women (2017) General Recommendation 35: Gender-Based Violence against Women, updating General Recommendation No. 19

${ }^{63}$ ILO Convention - Decent Work for Domestic Workers 2011, Article 5 and Committee on the Protection of the Rights of All Migrant Workers and Members of their Families (2013) General Comment No. 2: On the Rights of Migrant Workers in an Irregular Situation and Members of Their Families, U.N. Doc CMW/C/GC/2. 64 Beijing Declaration and Platform of Action, Adopted at the Fourth World Conference on Women, paragraph 165(b) and ILO Convention on Discrimination (Employment and Occupation), Article 2.
} 
discrimination encompasses older women workers, domestic, migrant and informal women workers. ${ }^{65}$ Meanwhile, a gender-regressive law would fail to impose sanctions or even permit dismissal on the grounds of pregnancy or maternity leave or discrimination in dismissals based on marital status ${ }^{66}$ or on the basis of family responsibilities. ${ }^{67}$

When it comes to the criteria of guaranteeing accessible and effective remedies (i.e. access to justice) (Criteria 6), a gender-responsive law would ensure all women workers have access to judicial and quasi-judicial mechanisms and remedies to women, ${ }^{68}$ specifically in relation to labour relations, including equal remuneration, social security entitlements, equal opportunities to be hired and promoted, and equal remuneration for civil servants. ${ }^{69}$ The law should incentivise the private sector to adopt protocols and procedures addressing all forms of gender-based violence that may occur in the workplace or affect women workers, including effective and accessible internal complaints procedures, the use of which should not exclude recourse to law enforcement authorities, and should also address workplace entitlements for victims/survivors. ${ }^{70} \mathrm{~A}$ gender-blind law, that fails to acknowledge the gender bias in judicial decision-making, would fail to allow for independent review in accordance with international standards by all decisions of administrative bodies; ensures that a decision rejecting an application is reasoned; and the claimant is able to appeal it to be a competent body. ${ }^{71}$ Such a law could easily cross into gender-regressive.

The Paid Parental Leave Act (2010) ${ }^{72}$ and the Dad and Partner Pay (2012) ${ }^{73}$ Amendment Acts are overarching examples of gender-responsive legislation, supporting mothers, fathers and same-sex partners to take leave after birth or adoptions. The significant weaknesses in both their legislative drafting and their substantive content - which risks promoting a normative

\footnotetext{
${ }^{65}$ International Convention on the Protection of the Rights of All Migrant Workers and Members of Their Families 1990 Article 7, ILO Convention - Decent Work for Domestic Workers, Article 6 and 7, United Nations Development Programme, 'Sustainable Development Goals (Goal 8.8),' http://www.undp.org/content/undp/en/home/sustainable-development-goals, 2018.

${ }^{66}$ Convention on the Elimination of All Forms of Discrimination against Women, Article 11(2)(a)).

${ }^{67}$ ILO Convention Concerning Equal Opportunities and Equal Treatment for Men and Women Workers: Workers with Family Responsibilities 1981, Article 8.

${ }^{68}$ Beijing Declaration and Platform of Action, Adopted at the Fourth World Conference on Women, pargraph165(r).

${ }^{69}$ Committee on the Elimination of Discrimination against Women (2015) General Recommendation 33: Women's Access to Justice, U.N. Doc. CEDAW/C/GC/33

${ }^{70}$ Committee on the Elimination of Discrimination against Women (2017) General Recommendation 35: Gender-Based Violence against Women, updating General Recommendation No. 19

${ }^{71}$ Committee on the Elimination of Discrimination against Women (2017) General Recommendation 35: Gender-Based Violence against Women, updating General Recommendation No. 19

${ }^{72}$ Paid Parental Leave Act 2010 (Cth).

${ }^{73}$ Paid Parental Leave and Other Legislation Amendment (Dad and Partner Pay and Other Measures) Act 2012 (Cth).
} 
family structure with birth mothers named as primary carers, ${ }^{74}$ and potentially widening gaps in inequality between men's and women's workforce participation rather than reducing them - are important to acknowledge. ${ }^{75}$ While welcomed legislative reforms, both laws are a pivotal reminder of the importance of gender-responsive provisions within gender-responsive laws to avoid undermining the law's potential impact in advancing shared caring.

\section{Taxation}

When it comes to standards for taxation, there is a general absence of comprehensive guidance when better address women's experiences of tax systems. This is despite substantial academic attention to the gendered-implications of the design and delivery of taxation. ${ }^{76}$ Much assistance was gained in the development of these standards from the 2019 European Parliament Resolution on Gender Equality and Tax Policies in the EU. ${ }^{77}$

When it comes to the criteria of guaranteeing access to information and education or require the provision of information and education (Criteria 2), a gender-responsive law would provide education on budgetary processes in relation to national income generated through taxation in order to help address marginalisation of civil society and advocacy groups from discussions on tax policy due to lack of expertise. ${ }^{78}$ When it comes to protecting women from particular situations of vulnerability (Criteria 5), a gender-regressive taxation system would contain particular biases against women when it comes to inheritance tax and social security systems. ${ }^{79}$

A neutrally applied value-added tax would indeed be gender-blind if it specifically placed the value-added tax on female hygienic products and care products and services for children, elderly people or people with disabilities. ${ }^{80}$ For income tax, joint tax "runs counter to the progress already achieved in promoting equality in employment" including for acting as a

\footnotetext{
${ }^{74}$ Paid Parental Leave Act (Cth) s 3A.

${ }^{75}$ De Alwis (2008), Chapman (2007), Baird and Cutcher (2005).

76 Cass and Brennan (2003) and Brooks et al (2011).

${ }^{77}$ European Parliament, 'Gender Equality and Taxation Policies in the EU (No 2018/2095(INI)', https://www.europarl.europa.eu/doceo/document/A-8-2018-0416_EN.html, 29 November 2018.

${ }^{78}$ European Parliament, 'Gender Equality and Taxation Policies in the EU (No 2018/2095(INI)', https://www.europarl.europa.eu/doceo/document/A-8-2018-0416_EN.html, 29 November 2018.

${ }^{79}$ Beijing Declaration and Platform of Action, Adopted at the Fourth World Conference on Women, paragraph 165(f).

${ }^{80}$ European Parliament, 'Gender Equality and Taxation Policies in the EU (No 2018/2095(INI)' http://www.europarl.europa.eu/doceo/document/A-8-2018-0416_EN.html, 15 January 2019)
} 
disincentive for women to return to employment after marriage or due to child care responsibilities. ${ }^{81}$

The above survey of examples across the three areas of law, illustrate the feasibility of using international law - primarily CEDAW - as a standard against which to assess the goal of achieving gender-responsive domestic legislation. It follows the view that, having ratified CEDAW, countries have committed to ensuring women have full enjoyment of their rights. This means following through on the legal and policy commitments made globally to guarantee positive changes in the lives of women and girls at the domestic level, in the form of genderresponsive legislation, regardless of the area of law.

\section{Conclusion}

The World Economic Forum's Gender Gap Index indicates it will take 108 years to close the global gender gap at the current rate of progress. ${ }^{82}$ That is unaffordable whether morally, socially, or economically. The McKinsey Global Institute research indicates that if women's participation in Australia fully equalled that of men, everyone in Australia would be $\$ 22,746$ richer. Simply matching best comparable country performance would yield a staggering economic gain for Australia of $\$ 220$ billion. ${ }^{83}$ So while the approach adopted in this research seeks to challenge the instrumentalisation of women and women's rights, the economics of the situation should garner political support. Gender inequality is a persistent global challenge that results in significant negative consequences for women and the societies in which women live. Australia is not alone: no country is on track to meet the 2030 United Nations gender equality targets. ${ }^{84}$

With most endeavours on gender equality failing, this article has offered a tangible contribution by using the law for the eradication of gender inequality. The project is anchored

\footnotetext{
${ }^{81}$ European Commission, Memorandum on Income Taxation and Equal Treatment for Men and Women (Memo P-94/84)

82 World Economic Forum, "The Global Gender Gap Report 2018', http://www3.weforum.org/docs/WEF_GGGR_2018.pdf, 2018.

${ }^{83}$ Council on Foreign Relations, 'Growing Economies through Parity', https://www.cfr.org/interactive/womensparticipation-in-global-economy/, 2019.

${ }^{84}$ Equal Measures 2030, 'Harnessing the Power of Data for Gender Equality: Introducing the 2019 EM2030

SDG Gender Index', https://data.em2030.org/wp-

content/uploads/2019/05/EM2030_2019_Global_Report_ENG.pdf, 2019.
} 
around the concept of gender-responsive legislation. Developing gender responsive legislation is a massive international challenge, calling for ambitious solutions. The challenge accepted in this article has been to provide sound and scalable examples to achieve gender-responsive legislation on a global scale. In doing so, it has answered the 'what' (what does genderresponsive legislation look like) and the how (how do these categories play out when it comes to specific areas of law).

To effectively measure how well the law addresses women's rights and needs, international law provides standards that can have applicability at a domestic level across civil, criminal and public law. CEDAW, alongside the other international human rights treaties, offer benchmarks for areas of law as diverse as health, labour, the environment, or finance and trade. Such an approach can facilitate the enactment of gender-responsiveness of laws in sectors such as financial services, taxation or the extractives industries - rarely considered from a gender perspective, despite the obvious need for such an approach.

This article has also provided to readers a sense of how far international law has come in developing standards for gender-responsive legislation at a domestic level and what areas of the law, such as taxation, need further work domestically and internationally for us to understand what a gender-perspective would look like. By using common standards, this approach also enables the creation of a tool that facilitates a comparison of where different countries across the globe are in terms of their legislative progress on women's rights. Such an index foresees a future where stronger tools for women's rights accountability translate into stronger domestic implementation of global standards.

\section{References}

\section{Primary Legal Sources}

Alyne da Silva Pimentel v Brazil [2011] UN Committee on the Elimination of Discrimination against Women Communication No. 17/2008

L C v Peru [2011] UN Committee on the Elimination of Discrimination against Women Communication No. 22/2009

Committee on the Elimination of Discrimination against Women (1990) General Recommendation 21: Equality in Marriage and Family Relations, U.N. Doc. A/45/38.

Committee on the Elimination of Discrimination against Women (1990) General Recommendation 24: Article 12 of the Convention, Women and Health, U.N. Doc. A/54/38 
Committee on the Elimination of Discrimination against Women (2015) General Recommendation 33: Women's Access to Justice, U.N. Doc. CEDAW/C/GC/33

Committee on the Elimination of Discrimination against Women (2017) General Recommendation 35: Gender-Based Violence against Women, updating General Recommendation No. 19

Committee on the Protection of the Rights of All Migrant Workers and Members of their Families (2013) General Comment No. 2: On the Rights of Migrant Workers in an Irregular Situation and Members of Their Families, U.N. Doc CMW/C/GC/2

Beijing Declaration and Platform of Action, Adopted at the Fourth World Conference on Women 1995 (1995) UN Doc. A/CONF. 177/20 (1995) and A/CONF.

Convention on the Elimination of All Forms of Discrimination against Women 1979 opened for signature Mar 1 1980, entered into force Sept. 31981.

ILO Convention - Decent Work for Domestic Workers 2011

ILO Convention Concerning Equal Opportunities and Equal Treatment for Men and Women Workers: Workers with Family Responsibilities 1981

ILO Convention on Discrimination (Employment and Occupation) 1958

ILO Convention on the Elimination of Violence and Harassment in the World of Work 2019

ILO Equal Remuneration Convention (No. 100) 1951

International Code of Marketing of Breast-Milk Substitutes 1981

International Convention on the Protection of the Rights of All Migrant Workers and Members of Their Families 1990

Paid Parental Leave Act 2010 (Cth)

Paid Parental Leave and Other Legislation Amendment (Dad and Partner Pay and Other Measures) Act 2012 (Cth)

Programme of Action of the United Nations International Conference on Population and Development 1994, UN Doc. A/CONF. 171/13

\section{Secondary Sources}

\section{A) Journal Articles and Books}

Marian Baird and Leanne Cutcher (2005) "“One for the Father, One for the Mother and One for the Country: "An Examination of the Construction of Motherhood through the Prism of Paid Maternity Leave' 31(2) Hecate 103 
Kim Brooks et al (2011) Challenging Gender Inequality in Tax Policy Making: Comparative Perspectives, Bloomsbury Publishing.

Chiara Carpraro (2016) 'Women's Rights and Fiscal Justice,' 24 Sur - International Journal on Human Rights 17

Bettina Cass and Deborah Brennan (2003), 'Taxing Women: The Politics of Gender in the Tax/Transfer System' 1 eJournal of Tax Research 37

Anna Chapman (2018) 'The Continuing Resonance of Breadwinner Norms: The Australian Labour Law Experience' 34(4) International Journal of Comparative Labour Law and Industrial Relations

Anna Chapman (2007) 'Uncovering the Normative Family of Parental Leave: Harvester, Law and the Household' 33(1) Hecate 28

Hilary Charlesworth (2018) 'Human Rights as Men's Rights' in JS Peters and Andrea Wolper (eds), Women's Rights, Human Rights: International Feminist Perspectives, Routledge.

Hilary Charlesworth and Christine Chinkin (2000) The Boundaries of International Law: A Feminist Analysis, Juris Publishing.

Rebecca J Cook (1991) 'International Protection of Women's Reproductive Rights' 24 New York University Journal of International Law and Politics 645

RJ Cook, BM Dickens and LE Bliss (1999) 'International Developments in Abortion Law from 1988 to 1998' 89(4) American Journal of Public Health 579

Meghan Cope (1997) 'Participation, Power, and Policy: Developing a Gender-Sensitive Political Geography’ 96(2) Journal of Geography 91

Bridget J Crawford and Carla Spivack (2017) 'Tampon Taxes, Discrimination, and Human Rights' 2017 Wisconsin Law Review 491

Kimberlé Williams Crenshaw (1988) 'Race, Reform, and Retrenchment: Transformation and Legitimation in Antidiscrimination Law’ 101(7) Harvard Law Review 1331

Malathi De Alwis (2008) 'Motherhood as a Space of Protect: Women's Political Participation in Contemporary Sri Lanka' in Patricia Jeffery and Amrita Basu (eds) Appropriating Gender: Women's Activism and Politicized Religion in South Asia, Routledge.

Valeria Esquivel and Caroline Sweetman (2016) 'Gender and the Sustainable Development Goals' 24(1) Gender \& Development 1

Prudence Flowers (2020) 'The Purists and the Pragmatists: The Right-to-Life Movement and the Problem of the Exceptional Abortion in the United States, 1980s-2010s' 78 Women's studies international forum

Barney G Glaser and Anselm L Strauss (1968) The Discovery of Grounded Theory: Strategies for Qualitative Research, Weidenfeld and Nicolson. 
Katherine Hay et al (2019) 'Disrupting Gender Norms in Health Systems: Making the Case for Change' 393(10190) Lancet 2535

Gina Heathcote (2012) 'Naming and Shaming: Human Rights Accountability in Security Council Resolution 1960 (2010) on Women, Peace and Security' 4(1) Journal of Human Rights Practice 82

Kathleen E Hull (2003) 'The Cultural Power of Law and the Cultural Enactment of Legality: The Case of Same-Sex Marriage' 28(3) Law \& Social Inquiry 629

Ratna Kapur (2013) 'Gender, Sovereignty and the Rise of a Sexual Security Regime in International Law and Postcolonial India’ 14 Melbourne Journal of International Law 29

Holly J Mccammon (1995) 'The Politics of Protection: State Minimum Wage and Maximum Hours Laws for Women in the United States, 1870-1930' 36(2) The Sociological Quarterly 217

Jenni Millbank (2021) 'Gender-Transformative Law Reform as Healthcare' in Ramona Vijeyarasa (ed) International Women's Rights Law and Gender Equality: Making the Law Work for Women, Routledge.

Dianne Otto (2019) 'Afterword: The Future(s) of Feminist Engagement with International Law' in Research Handbook on Feminist Engagement with International Law, Edward Elgar Publishing.

Dianne Otto (2017) 'Introduction: Embracing Queer Curiosity' in Dianne Otto (ed) Queering International Law: Possibilities, Alliances, Complicities, Risks, Taylor and Francis

Tamsin Phillipa Paige, 'The Maintenance of (International Peace and Security) Heteronormativity' in Dianne Otto (ed) Queering International Law: Possibilities, Alliances, Complicities, Risks, Taylor and Francis

Jaya Ramji-Nogales (2019) 'Revisiting the Category "Women:" Research Handbook on Feminist Engagement with International Law' in Research Handbook on Feminist Engagement with International Law, Edward Elgar Publishing

Kim Rubenstein and Katharine G Young (2016) The Public Law of Gender: From the Local to the Global, University Press.

Carol Smart (1989) Feminism and the Power of Law, Routledge

Miranda Stewart (2017) 'Gender Inequality in Australia's Tax-Transfer System' in Miranda Stewart (ed) Tax, Social Policy and Gender, ANU Press.

Janet Gale Stotsky (1996) Gender Bias in Tax Systems, IMF Working Paper No 96/9

J Ann Tickner (2004) 'The Gendered Frontiers of Globalization' 1(1) Globalizations 15

Jacqui True (2005) 'Mainstreaming Gender in Global Public Policy' 5(3) International Feminist Journal of Politics 368 
Cathy Urquhart (2013) Grounded Theory for Qualitative Research: A Practical Guide, SAGE Publications.

Ramona Vijeyarasa (2019) 'Making the Law Work for Women: Standard-Setting through a New Gender Legislative Index’ 44(4) Alternative Law Journal 275

Ramona Vijeyarasa (2021) 'Quantifying CEDAW: Concrete Tools for Enhancing Accountability for Women's Human Rights' 34 Harvard Human Rights Journal

Ramona Vijeyarasa (2010) 'Scrutinizing Vietnam’s Progress Towards Gender Equality’ 53(1) Development 91

Ramona Vijeyarasa (2013) 'Women at the Margins of International Law: Reconceptualizing Dominant Discourses on Gender and Transitional Justice' 7(2) International Journal of Transitional Justice 358

Lena Wangnerud (2015) The Principles of Gender-Sensitive Parliaments, Routledge Elizabeth Warren (2002) What Is A Women's Issue? Bankruptcy, Commercial Law, and Other Gender-Neutral Topics 25 Harvard Women's Law Journal

Nancy Woloch (2015) 'Introduction' in A Class by Herself, Princeton University Press)

World Bank, 'Women, Business and the Law 2019: A Decade of Reform' https://openknowledge.worldbank.org/bitstream/handle/10986/31327/WBL2019.pdf?sequenc $\mathrm{e}=4$ \&isAllowed $=\mathrm{y}, 2019$.

Christina Zampas and Jaime M Gher (2008) 'Abortion as a Human Right_-International and Regional Standards' 8(2) Human Rights Law Review 249

\section{B) Reports}

European Commission, Memorandum on Income Taxation and Equal Treatment for Men and Women (Memo P-94/84)

European Parliament, 'Gender Equality and Taxation Policies in the EU (No 2018/2095(INI)' https://www.europarl.europa.eu/doceo/document/A-8-2018-0416_EN.html, 28 November 2018.

UN Women, 'Safe Cities and Safe Public Spaces: Global Results Report,'

$<$ http://www.unwomen.org/en/digital-library/publications/2017/10/safe-cities-and-safepublic-spaces-global-results-report>, 2017

World Economic Forum, 'The Global Gender Gap Report 2020 http://www3.weforum.org/docs/WEF_GGGR_2020.pdf.

\section{C) Websites}

ActionAid, 'Safe Cities for Women,' http://www.actionaid.org/safecitiesforwomen 2016 
Council on Foreign Relations 'Growing Economies through Parity,' https://www.cfr.org/interactive/womens-participation-in-global-economy/, 2019.

Equal Measures 2030, Harnessing the Power of Data for Gender Equality: Introducing the 2019 EM2030 SDG Gender Index (Equal Measures 2030, 2019) <https://data.em2030.org/wp content/uploads/2019/05/EM2030_2019_Global_Report_ENG.pdf>

European Institute for Gender Equality, 'Area 4: The Parliament Produces Gender-Sensitive Legislation,' https://eige.europa.eu/gender-mainstreaming/toolkits/gender-sensitiveparliaments/examples-gender-sensitive-practices-parliaments/area-4-parliament-producesgender-sensitive-legislation, 2020.

Group of 7, 'Making Gender Equality a Global Cause,' https://www.elysee.fr/admin/upload/default/0001/05/2d0396362dbe1 fb85faccb8e 1 f5dbefce5a 0b09e.pdf

Office of the High Commissioner for Human Rights, 'Working Group on Discrimination against Women and Girls,' https://www.ohchr.org/en/issues/women/wgwomen/pages/wgwomenindex.aspx, 2019

United Nations Development Programme, 'Sustainable Development Goals,' http://www.undp.org/content/undp/en/home/sustainable-development-goals/, 2018

World Justice Project, 'Rule of Law Index 2020'

Https://worldjusticeproject.org/sites/default/files/documents/WJP-ROLI-2020-Online_0.pdf, 2020 . 